\title{
猃 壇
}

\section{法学教育と \\ 司法試験の科目変更}

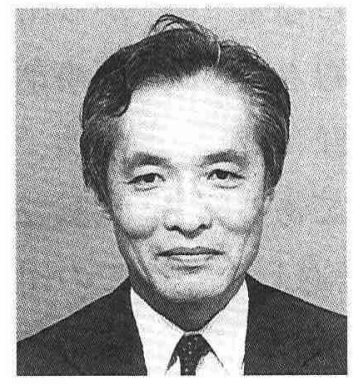

山田 二郎

\section{I 法学教科とカリキュラムの改革}

どの大学の法学部でも、ここ数年来カリキ ユラムの改革に取り組んでいる。特に私立大 学ではその生存をかけて懸命に取り組んでい る。私の大学では1997年4月から全学あげてセ ミスター制 (通年の講義から半年単位の集中の 講義へ) を導入したことと相まって、法学教育 の充実、活性化に特に熱心に取り組んできた。 その主眼は、一口でいうと、法学教育の活性 化である。1 年生に基礎ゼミを設けて法律の勉 強の手ほどき、特にコンピューターを利用する 学習方法にアクセスすることにしたり、法律の 勉強に興味を持たせるように専門科目をでき るだけ低学年に下ろすことにしたことなどで
ある。

しかし、外国語の単位数を減らしたり、3 年 生と4年生のゼミを必修科目から選択科目にし たり、必修科目数を減らして選択科目にした りしたことについては：その功罪について批判 もかなり強く、経過観察を必要とする課題と なっている。

\section{II 法学教育に何を求めたらよいのか}

法学部の卒業生の大半は一般企業に就職す る。一般企業の法務部門で活躍するというわ けでもない。司法試験や国家公務員試験、地 方公務員試験、税理士試験などに挑戦しよう とする学生は少数派である。修学年限の大き 
な制約があり、法学教育の中で専門科目を深 く教えることは無理で、これまではともかく法 律的なものの考え方、換言するとリーガルマイ ンドを身につけさせればよいのではないかとい われてきた。果たしてこのようなことでよいの であろうか。リーガルマインドを身につけると いうことは最低限のことであり、専門的な学 習をできるだけ行い、法的な専門的分野に関 心をもたせるように仕向けることが大事である ように考えられる。戦後 50 年以上が経過し、 新憲法の施行後 50 年の検証が行われているが、 わが国に本当に民主主義が定着したといえる のか問われている。「法の支配」が浸透していな いこと、特に平等原則、財産権の保障、租税 法律主義など言葉だけが一人歩きしているだ けで、実体を伴っていないことを憂慮している 声が強い。

わが国に「法の支配」が浸透していない大き な理由として、国民の権利が手続上保障され ていなかったことが大きな理由として挙げられ ている。これを改善するために、漸く1994年 10月1日から行政手続法が施行となり、情報 公開法も近く制定されることになり、また今年 1月1日から新民事訴訟法が施行された。国民 の権利は、行政情報が公開され、行政が適正 な手続きで執行され、裁判所が国民の権利を 積極的に守ることによってはじめて実質的に 保障されるものであり、これらの新法の施行に よって「法の支配」に新しい展望が開かれるこ とが期待されている。法学教育もこれらの新し
い展開に寄与できるものでなければならない。

\section{III 司法試験の科目変更の是非}

司法制度の改革の一環として、現役を司法 試験に合格しやすくするために、平成 12 年度 から司法試験の科目を変更し、民事訴訟法と 刑事訴訟法をともに必修とする代わりに、行 政法、労働法などの選択科目を廃止する司法 試験法の改正が提出されることになっている。 この司法試験の科目変更については、阿部泰 隆神戸大学教授をはじめ多くの学者が反対意 見を述べており（阿部泰隆「司法試験に、行政 法は不可欠だ」朝日新聞平成 10 年 2 月 17 日、 同「司法試験行政法廃止は法治国家の危機」 ジュリス1128号41頁など)、日本学術会議 第2 部会の議題として取り上げており、また日 本学術会議の第17期公法学研連の審議テーマ としても取り上げられている。司法試験の科 目の変更は、右意見にも述べられているよう に、司法試験に現役の合格者を増やすという 目先のことだけで結論を出すべきものではな く、法学教育に与える影響が大きいことであ り、またわが国の「法の支配」の現状を考え、 これを改善するという広い視野に立った判断 が必要なことである。

司法試験の科目から行政法、労働法などの 法律専門科目が廃止されると、学生のこれら の科目に対する学習志向が低下してしまうこ とは必定である。これでよいのであろうか。特 に現状では、法治国家の空洞化が強く憂慮さ 
れているので、行政法や労働法などの専門科 目に、学生、将来の法曹 (裁判官、検察官、弁 護士)に法的な基礎知識をしっかりと学習させ る必要性を痛感している。民事訴訟法や刑事 訴訟法は、むしろ法曹の研修期間 (司法研修 所の教育)でみっちり教育すればよいのではな かろうか。

\section{IV むすびに代えて}

このたびの司法試験の科目の変更は、法学 教育ひいては法曹に不可欠な法的知識の学習 に影響するところが大きい。私は、司法試験 の科目の変更は、非常に近視眼的な発想で、
日本の扔かれている法的状況、将来のある心゙ き法的状況を展望したものでないことを憂慮 している。民主主義、「法の支配」を日本に定 着させるためには、訴訟手続の技術的な知識 よりも、国民の基本的人権、公正・透明な行 政運営を確保する法的スキームに法的興味 をかり立て、これらのことをしっかりと学習さ せることが必要なことであると考えている。
山田 二郎（やまだじろう 1930年生）

公法学研究連絡委員会委員、租税法学会理事、日本税法学会名 誉理事、財政法学会監事、日本土地法学会東京支部監事、東海 大学教授・前法学部部長、元東京高等裁判所判事

専門：租税法、行政法

\section{新捂介 日本学術協力財団の出版図書}

\section{日学双書27「明日の震災にどう備えるか〜阪神・淡路大地震の教訓を踏まえて〜」から} 一日本学術会議主催公開講演会における記録—

\section{日本学術会議主催公開講演会}

「明日の震災にどう備えるか〜阪神・淡路大地震の教訓を踏まえて〜」から

\section{1 日本列島の地震とその観測体制}

尾池 和夫 (地震学研究連絡委員会委員長、京都大学大学院理学研究科教授)

2 災害救急医療体制はどこまで整ったか 小林 国男 (救急·麻醉·集中治療医学研究連絡委員会委員、帝京大学医学部救命救急センター教授)

3 都市計画と建物の災害について 内田 祥哉（日本学術会議第 5 部会員、東京大学名誉教授）

(4) 住宅復興の現状と残された課題 大野 喜久之輔（経済政策研究連絡委員会委員、広島市立大学図書館長、国際学部教授）

(5) 震災復興とその法的課題 大西 泰博 (社会法学研究連絡委員会委員、早稲田大学社会科学部教授)

6 地元住民としての所感〜緑地とコミュニティーの役割〜 松中 昭一 (日本学術会議第 6 部会員、関西大学工学部教授) 